УДК 004.942:338

\author{
${ }^{[0000-0002-9037-6479]}$ Б. В. Мисник, к.т.н., \\ ${ }^{[0000-0003-1039-6988]}$ Р. Б. Капітан, к.т.н., доцент, \\ [0000-0002-7653-9569] Л. Д. Мисник, к.т.н., доцент, \\ [0000-0001-6872-2948] О. В. Манзюра \\ Черкаський державний технологічний університет \\ б-р Шевченка, 460, м. Черкаси, 18006, Україна \\ e-mails: b.mysnyk@chdtu.edu.ua, 1.mysnyk@chdtu.edu.ua,kapitan_ruslan@ukr.net, \\ fktm-email@ukr.net

\section{ПРОБЛЕМИ ІНФОРМАЦІЙНО-АНАЛІТИЧНОГО СУПРОВОДУ ФУНКЦІОНУВАННЯ І РОЗВИТКУ ПІДПРИСМСТВ ПОЛІГРАФІЧНОЇ ГАЛУЗІ В УМОВАХ КОНКУРЕНЦІї}

Стаття присвячена аналізу процесів прийняття рішень на підприємствах, використанню мультиагентних систем до моделювання процесів функціонування і розвитку підприємств поліграфічної галузі, які представлені окремими агентами з однаковою архітектурою і програмами, що відрізняються побічними і додатковими функціями. Розглянуто моделювання процесів життєвого циклу підприємства з використанням інтелектуальних агентів, кожний $з$ яких має внутрішню структуру (міжмодульні зв'язки), елементний базис (програмні модулі для розв'язання окремих задач), використовує дані (як внутрішні для підприємства, так $i$ з загальної бази даних), робить висновки (на основі даних та, виходячи із прагнення розвитку та максимізаиії прибутку). Проведена формалізачія задачі оптимізації діяльності підприємства галузі. Запропонована модель, що поєднує в собі принципи роботи сучасних економічних математичних моделей з внесеними змінами для інтегращиї принципів концепщї «штучного жит$m я »$.

Ключові слова: штучне життя, оптимізачія функиіонування, мультиагентна система, прийняття рімень, моделі показників ефективності.

Вступ. Основними агентами сучасної економіки України є малі та середні підприємства. Процес їх виникнення, існування та зникнення в умовах конкурентного середовища $є$ швидкоплинним та малопередбачуваним. Перед їх керівниками постійно виникають задачі розширення виробництва, перепрофілізації, модернізації, створення філій або ліквідації. Через недостатнє інформаційноаналітичне забезпечення приймаються необгрунтовані, помилкові рішення, що призводить до значних економічних втрат або зниження динаміки економічного росту. Особливо актуальними ці задачі $є$ для підприємств галузей, що випускають однорідну продукцію, зокрема для поліграфічних підприємств.

Проблеми прийняття рішень та оптимізації функціонування економічних систем розглядались у роботах класиків Л.В.Канторовича, Д. М. Кейнса， М. Д. Кондратьєва, В.В.Леонтьєва, О. Моргенштерна, Д. фон Неймана та інших. У 90-х роках мину- лого століття було помічена подібність мультиагентних та економічних систем, що дозволяє застосувати методи теорії мультиагентних систем до моделювання процесів функціонування підприємств. Процеси моделювання діяльності підприємств, технології прийняття рішень, у т.ч. і на основі еволюційної парадигми, знаходяться в основі підвищення ефективності етапів їх життєвого циклу та були відображені у роботах відомих вчених О. Ф. Волошина, Л. Ф. Гуляницького, Ю. П. Зайченка, В. Е. Снитюка [1-4] й інших.

Розвиток теорії та розробка практичних застосувань мультиагентних систем для аналізу та прогнозування підприємств поліграфічної промисловості $\epsilon$ важливою умовою їх розвитку та ефективного функціонування. Таким чином, задача розробки моделей, методів та інструментальних засобів підтримки прийняття рішень щодо оптимізації функціонування підприємств галузі є важливою і актуальною. 
Метою дослідження $є$ аналіз процесів прийняття рішень на підприємствах поліграфічної промисловості, а також ідей, принципів, моделей, методів підтримки прийняття рішень, які застосовуються для аналізу та оптимізації функціонування підприємства.

Виклад основного матеріалу. Для стабільного економічного розвитку країни важливим $\epsilon$ збільшення частки приватних малих та середніх підприємств. Цей факт, а також те, що діяльність кожного підприємця спрямована на одержання прибутку, і те, що, як правило, ринок галузевої продукції є обмеженим та 3 часом насичується, свідчать про необхідність оптимізації функціонування підприємств галузі та підвищення ефективності управлінських рішень їх керівниками.

Як відомо, прогрес у будь-якій сфері людської діяльності реалізується внаслідок ідеї або необхідності. І саме у підприємництві на початковому етапі життєвого циклу бізнесової діяльності ці два концепти тісно інтегровані один в інший. Етап функціонування має більш реалістичні аспекти, в його основі лежить саме необхідність, необхідність одержання прибутку для виплати зарплат, соціального захисту, реалізації екологічних заходів тощо. Плануючи створення нового підприємства, здійснюючи управління його функціонуванням, передбачаючи потребу модернізації чи переходу на випуск нової продукції, особа, яка приймає рішення, обов'язково стикається 3 проблемою прогнозування роботи цього підприємства й визначення його прибутковості, тобто «погляду на майбутнє». Такі дії означають вирішення проблеми передбачення процесів життєвого циклу виробництва. Найчастіше подібне прогнозування полягає у застосуванні ідентифікованих залежностей результуючих характеристик від вхідних факторів.

На поліграфічне підприємство впливають різноманітні фактори - як зовнішні, так і внутрішні, та їх динаміка. Врахувати всю множину таких факторів неможливо, але це і непотрібно, так як величина їх може бути вирахувана хибно, і значна кількість факторів веде до збільшення похибок. Все це свідчить про потребу використання нових методів моделювання процесів функціонування поліграфічного підприємства.

(C) Б. В. Мисник, Р. Б. Капітан, Л. Д. Мисник, О. В. Манзюра, 2020 DOI: $10.24025 / 2306-4412.2 .2020 .197895$
Адекватне реальним процесам моделювання може бути здійснено, якщо чисельні значення характеристик діяльності підприємств можливо занести в базу даних, яка ідеалізовано вважається релевантною всім підприємствам галузі. Дискретність даних визначається часом здійснення будь-якої транзакції на будь-якому підприємстві.

Використання елементів мультиагентної парадигми $є$ не тільки доцільним, але i необхідним. Які причини спонукають до такого висновку?

По-перше, і виробничі підприємства, i мультиагентні системи $(M A C)$ мають архітектуру і функціонують за заданими програмами, що вказує на їх дуальність [5-8].

По-друге, i ті, й інші допускають модульну декомпозицію, що дозволяє здійснювати їх аналіз, а при необхідності і синтез, адже, як відомо, працююча складна система є результатом роботи простих систем.

I, по-третє, наявність загальної властивості системності [9-12] визначає присутність як конкуренції, так і кооперації при існуванні у відносно замкнутому середовищі і рішення однотипних завдань.

На користь застосування мультиагентних систем як деякої парадигми моделювання свідчить той факт, що кожне підприємство в економіці можна представити окремим агентом, а підприємство галузі, зокрема поліграфічної - ще й агентом з однаковою архітектурою і програмами, що відрізняються тільки побічними і додатковими функціями. Зауважимо, що теорія мультиагентних систем на сьогоднішній день досить розвинена, а математичний апарат і програмно-алгоритмічне забезпечення визначаються, зокрема, і специфікою вирішуваних завдань [13].

Керівник кожного підприємства в процесі його функціонування постійно приймає рішення щодо модернізації, зміни спектру вирішуваних завдань, структури виробництва, розподілу ресурсів на підставі знань, досвіду та інтуїції. Керівник визначає стратегію і тактику розвитку підприємства, але у більшості випадків його діяльність $є$ оперативною реакцією на поточний стан навколишнього середовища та значення параметрів підприємства. Критичність впливу фактору часу призводить до невірних або стратегічно провальних рішень. 
Негативні наслідки таких рішень можна виключити, використовуючи прогнозування і аналіз можливих сценаріїв розвитку подій. Відповідним інструментарієм можуть бути $M A C$. Агентом, в даному випадку, $є$ деяка сутність, що призначена для автономного функціонування, а також для підтримки прийняття рішень особі, що приймає рішення (ОПР). Кожний агент має внутрішню структуру (міжмодульні зв'язки), елементний базис (програмні модулі для розв'язання окремих задач), використовує дані (як внутрішні для підприємства, так і з загальної бази даних), робить висновки (на основі даних та, виходячи із прагнення розвитку та максимізації прибутку). Зауважимо, що метою функціонування агента $є$ отримання максимального прибутку підприємством як інтеграція розв'язків однієї з задач різними методами, так і надання рекомендацій щодо модифікації процесу функціонування підприємства [14].

Виконаємо формалізацію задачі оптимізації діяльності підприємства галузі.

Нехай $W=\left\{\mathrm{S}_{1}, \mathrm{~S}_{2}, \ldots, \mathrm{S}_{n}\right\}-$ множина підприємств галузі, $n \geq 2$. Будемо вважати, що функціонування підприємства $S_{i}$ визначається трійкою елементів

$$
S_{i}=<X_{i}, Y_{i}, Z_{i}, t>\text {, }
$$

де $X_{i}$ - вхідні фактори системи, $Z_{i}$ - параметри внутрішнього стану, $X_{i}$ - вихідні характеристики системи $S_{i}, t-$ час.

Стан системи $S_{i}$ в момент часу $t$ визначається значеннями її показників, тобто

$$
S_{i}=<x_{i t}^{1}, x_{i t}^{2}, \ldots, x_{i t}^{n x}, \mathrm{z}_{i t}^{1}, \mathrm{z}_{i t}^{2}, \ldots, \mathrm{z}_{i t}^{n z}, \mathrm{y}_{i t}^{1}, \mathrm{y}_{i t}^{2}, \ldots, \mathrm{y}_{i t}^{n y}>
$$

де $x_{i t}^{j}$ - значення $j$-го вхідного фактора в момент часу $t$ (ціна обладнання, доставленого на підприємство), $j=\overline{1, n_{x}} ; z_{i t}^{j}-$ значення $j$-го внутрішнього параметра (собівартість одиниці продукції), $j=\overline{1, n_{z}} ; y_{i t}^{j}-$ значення $j$-ї вихідної характеристики (дохід від продажу одиниці продукції), $j=\overline{1, n_{y}}$.

Будемо вважати будь-які зміни будьякого значення 3 (2) транзакціями. Моменти часу, коли відбуваються транзакції, дискретизують часовий інтервал функціонування підприємства $T=\left\{t_{0}<t_{1}<t_{2}<\ldots\right\}$.

Вихідні характеристики підприємства або їх комбінації здійснюють вплив на функ-

(C) Б. В. Мисник, Р. Б. Капітан, Л. Д. Мисник, О. В. Манзюра, 2020 DOI: $10.24025 / 2306-4412.2 .2020 .197895$ ціонування підприємства i їх ефективність оцінюється показником $P_{i}^{k}$, тобто

$$
P_{i}^{k}=P_{i}^{k}\left(S_{i}\right)=P_{i}^{k}\left(Y_{i}\right)=P_{i}^{k}\left(y_{i t}^{1}, y_{i t}^{2}, \ldots, y_{i t}^{n y}\right),
$$

де $k=\overline{1, l}, l-$ кількість показників ефективності.

Тоді інтегральний показник - інтегральний критерій ефективності підприємства матиме вигляд:

$$
\begin{gathered}
E_{i}=E_{i}\left(P_{i}^{1}, P_{i}^{2}, \ldots, P_{i}^{l}\right)=E_{i}\left(P_{i}^{1}\left(Y_{i}\right), P_{i}^{2}\left(Y_{i}\right), \ldots, P_{i}^{l}\left(Y_{i}\right)\right) . \\
\text { У свою чергу, } Y_{i}=F_{i}\left(X_{i}, Z_{i}\right), \text { тому }
\end{gathered}
$$$$
E_{i}=E_{i}\left(P_{i}^{1}\left(F_{i}\left(X_{i}, Z_{i}\right)\right), P_{i}^{2}\left(F_{i}\left(X_{i}, Z_{i}\right)\right), \ldots, P_{i}^{l}\left(F_{i}\left(X_{i}, Z_{i}\right)\right)\right) \text {. (4) }
$$

Враховуючи те, що ринок продукції, яка виробляється підприємством галузі, має обмежену ємність, максимальний прибуток $E_{\max }$ могло б отримати єдине підприємство на ринку за відсутності конкуренції, наявності достатньої ресурсної та кадрової бази. Оскільки раніше така ситуація виключена $(n \geq 2)$, то для кожного підприємства необхідно розв'язувати задачу $E_{i} \rightarrow E_{i \max } \forall t \in T$, де $T-$ інтервал часу функціонування підприємства, $i=\overline{1, n}$.

Підкреслимо, що розв'язання такої чи таких задач здійснюється в умовах невизначеності, що пов'язано із невизначеністю цілей, умов зовнішнього середовища, обмежень як об'єктивного, так і суб' єктивного характеру. Неповнота, неоднозначність, відсутність та суперечливість даних супроводжують процеси прийняття рішень на всіх етапах життєвого циклу підприємств галузі. Не існує такого етапу, на якому прийняття рішень мало б детермінований характер. Це твердження стосується як етапу визначення доцільності створення підприємства, так і етапів безпосереднього заснування, функціонування, модернізації чи ліквідації.

Окреме поліграфічне підприємство зобразимо як систему $S$, поведінка якої є неперервно-дискретним процесом і задається функцією

$$
F(t)=\left\{\begin{array}{c}
f_{1}(t), t \in\left[t_{0}, t_{1}\right], \\
f_{2}(t), t \in\left[t_{1}, t_{2}\right], \\
\ldots \ldots \ldots \ldots \ldots \ldots \ldots . . \\
f_{k}(t), t \in\left[t_{k-1}, t_{k}\right], \\
\ldots \ldots \ldots \ldots \ldots . .
\end{array}\right.
$$

Функції $f_{i}(t)$ визначають показники ефективності функціонування системи: при- 
буток, собівартість продукції, енергоємність, фондоозброєність тощо. Переходи $f_{i}(t) \rightarrow f_{i+1}(t)$ здійснюються в результаті прийняття певних рішень в часові моменти $t_{i}$. Визначимо, які фактори впливають на появу таких значень $t_{i}$. Дослідимо систему $S$ як елемент системи вищого ступеня ієрархії яку позначимо $\Omega$.

Системи $S$ і $\Omega$ впливають одна на одну, обмінюючись енергією $(E)$, коштами $(U)$, інформацією $(I)$, кадрами $(R)$, матеріалами $(H)$ та іншими даними (рис. 1). Оскільки всі системи $S_{i}, i=\overline{1, n}$, здійснюють такий взаємообмін з $\Omega$, то очевидно, що мають місце відображення $\quad S_{i} \rightarrow \Omega \rightarrow S_{j}, \quad S_{j} \rightarrow \Omega \rightarrow S_{i}, i \neq j$. Зауважимо, що кожне відображення $G_{i j}: S_{i} \rightarrow S_{j}$ має різні кількісні та якісні показники. При цьому взаємообмін здійснюється на вже вказаних сімох рівнях. Має місце система відображень

$$
\begin{aligned}
& \Omega \rightarrow S_{j}^{\text {in }}\left(H_{j}, E_{j}, I_{j}, U_{j}, R_{j}\right) \rightarrow \\
& \rightarrow S_{j}^{\text {out }}\left(P_{j}, D_{j}\right) \rightarrow \Omega, \forall j=\overline{1, n} .
\end{aligned}
$$

Оскільки перетворення (6) є замкненим, то його можна представити у вигляді:

$$
\begin{gathered}
\Omega_{\text {in }}^{i} \rightarrow \Omega_{\text {out }}^{i}, \\
\Omega_{\text {in }}^{i+1}=V\left(\Omega_{\text {out }}^{i}\right)=V\left(\left(P_{j}, D_{j}\right), \forall j=\overline{1, n}\right) .
\end{gathered}
$$

Вирази (6) і (7), показують взаємовплив системи вищого ступеня ієрархії $\Omega$ з кожною $3 S_{j}$. В результаті відбуваються зміни у вхідних потоках наступних періодів часу систем $S_{j}$. Тому вважаємо, що наступає $t_{i}$, коли $\exists S_{j}$ , в яку надходить $H_{j} \vee E_{j} \vee I_{j} \vee U_{j} \vee R_{j}$, або з якої отримують $P_{j} \vee D_{j}$, і цей час $t_{i}>t_{i-1} \epsilon$ мінімальним для $\forall S_{j}, j=\overline{1, n}$.

Матері альні потоки, Інформація, Енергія, Кадри, Фінанси

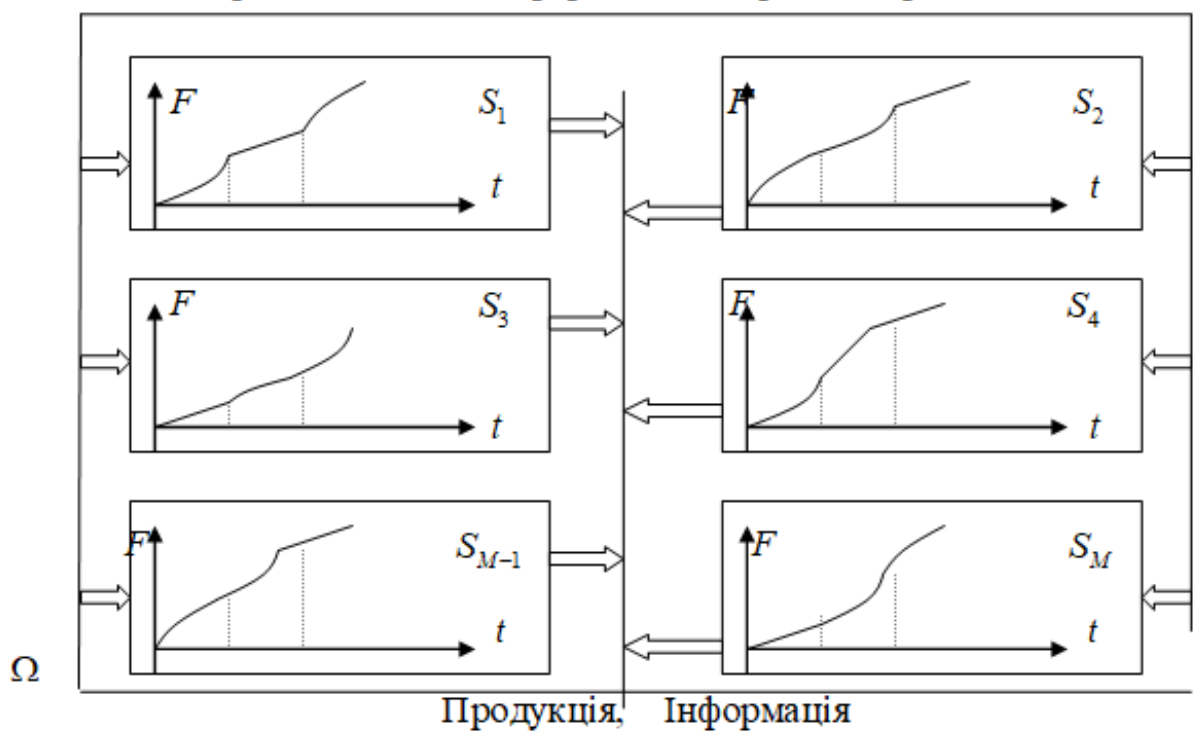

Рисунок 1 - Взаємодія підприємств як мультигентна технологія

На рис. 1 також показано, як змінюються функції $f_{i}(t)$ в різні моменти часу. Це може бути величина (тираж) виготовленої продукції, так як показані функції монотонні.

Таким чином, MAC буде враховувати інформацію ззовні у моменти часу $t_{i}, i=\overline{0, L}$, і це дасть можливість змінювати стратегію діяльності підприємства.

Підприємства функціонують в деякому середовищі, з якого вони отримують ресурси, енергію та інформацію, і в яке вони віддають

(C) Б. В. Мисник, Р. Б. Капітан, Л. Д. Мисник, О. В. Манзюра, 2020 DOI: $10.24025 / 2306-4412.2 .2020 .197895$ продукцію. Процеси життєвого циклу підприємства можуть бути промодельовані $з$ використанням інтелектуальних агентів.

Інтелектуальність розуміємо як здатність вирішувати слабко структуровані задачі, тому інтелектуальне моделювання функціонування підприємства - це не тільки обчислення модельних значень, а й вироблення практичних рекомендацій у залежності від їх комбінації.

Припускаємо, що дії виконуються в інтересах одного поліграфічного підприємст- 
ва $S^{*}$. Час його життєвого циклу вважаємо дискретним $T=\left\{t_{0}, t_{1}, \ldots, t_{p}, \ldots, t_{q}, \ldots t_{m}\right\}$. Моменти часу $t_{i}, i \in\{0,1, \ldots, m\}$ визначаються транзакціями в системі на будь-якому 3 підприємств галузі. Під транзакціями розуміємо будь-яку взаємодію підприємства 3 середовищем, наслідком чого $є$ зміна кількісних характеристик хоча б одного $з$ підприємств.

Особливістю процесів прийняття рішень на підприємстві галузі є невизначеність вихідної інформації про функціонування підприємств-конкурентів або підприємствпартнерів.

Вихідною інформацією для функціонування агента $\epsilon$ дані із загальної бази транзакцій, а отримані агентом результати використовуються для прийняття рішень в оперативному, тактичному і стратегічному планах.

Відзначимо, що в основі прийняття рішень можуть лежать як чіткі, так і нечіткі продукційні правила типу

$$
\text { Якщо } \&_{j=1}^{J} x_{j} \in A_{j}, m o\left\{\begin{array}{l}
\underset{j}{\&} y_{j} \in B_{j} \vee \\
I \quad J \\
\underset{i=1}{V} \& y_{j=1} y_{i j} \in C_{i j},
\end{array}\right.
$$

де $X=\left\{x_{1}, x_{2}, \ldots, x_{J}\right\}-$ множина вхідних фактоpiв, $Y^{1}=\left\{y_{1}, y_{2}, \ldots, y_{J}\right\}$ і $Y^{2}=\left\{y_{11}, y_{12}, \ldots, y_{I J}\right\}-$ множина результуючих характеристик функціонування підприємства, $A_{j}, B_{j}, C_{i j}-\mathrm{y}$ загальному випадку нечіткі множини зі своїми функціями належності, $i=\overline{1, I}, j=\overline{1, J}$.

Правила (8) необхідні для того, щоб визначити спектр задач, які потрібно розв'язувати керівництву на підприємстві; сформувати структуру виробництва i здійснювати певну стратегію управління. При цьому необхідні дані, які можуть з'явитися тільки у віддаленій перспективі.

Позначимо $t_{p}$ - поточний момент часу, $t_{q}-$ час, коли можуть з'явитися відсутні дані, $p<<q$. Побудуємо модель

$$
R\left(t_{p}\right)=H\left(R\left(t_{p}-\right), \operatorname{In}\left(t_{p}\right), \operatorname{Out}\left(t_{p}\right)\right),
$$

де $R\left(t_{p}\right)$ - деяка характеристика або показник в момент часу $t_{p}, R\left(t_{p}-\right)$ - показник інтегрованої динаміки характеристики до моменту часу $t_{p}$, $\operatorname{In}\left(t_{p}\right)$ і $\operatorname{Out}\left(t_{p}\right)$ - значення внутрішніх і зовнішніх для підприємства $S^{*}$ факторів, відповідно.
Проблема отримання залежності (9) полягає в тому, що значення зовнішніх факторів для підприємства часто невідомі і їх необхідно відновлювати, використовуючи аналітичні методи або експертні процедури.

Аналізуючи ефективність функціонування окремого підприємства і усієї галузі, необхідно розглядати множину їх характеристик. Вважаючи, що стан підприємства визначається їх значеннями, вважатимемо, що

$$
S_{j}=<X_{j}^{1}, X_{j}^{2}, \ldots, X_{j}^{d j}>,
$$

де $S_{j}$ - j-е підприємство, $\left(X^{l}, X^{2}, \ldots, X^{d}\right)$ - характеристики підприємства, причому

$$
S_{j}^{t}=\left(x_{j}^{1 t}, x_{j}^{2 t}, x_{j}^{d j t}\right),
$$

де $t$ - час, причому $\exists k \in[1 ;+\infty): t \in\left[t_{k-1}, t_{k}\right]$, $x_{j}^{i t}$ - значення характеристики $X^{i} j$-го підприємства в момент часу $t$.

Вирази (10) і (11) дають можливість побудови моделі траєкторії функціонування підприємств галузі, двовимірний варіант якої наведено на рис. 2. У загальному випадку така модель може бути записана як $F_{M}=<X_{1}^{1}, X_{1}^{2}, \ldots, X_{1}^{d}, X_{2}^{1}, X_{2}^{2}, \ldots, X_{2}^{d}, \ldots, X_{M}^{1}, X_{M}^{2}, \ldots, X_{M}^{d}>$

Таким чином, наведена модель $є(M+1)$ вимірним прямокутним гіперпаралелепіпедом, що наочно показує напрям діяльності підприємства з врахуванням зовнішніх і внутрішніх факторів. Довжина однієї із сторін гіперпаралелепіпеда збільшується, оскільки відповідає часу. Крім того, стверджуємо, що одночасно ніякі дві траєкторії функціонування підприємств не проходять через одну комірку, що пояснюється різноманітністю підприємств та значень їх характеристик. Зауважимо, що для них існують обмеження, тобто $\forall X_{j} \in\left[X_{j \min }, X_{j \max }\right]$. Якщо значення хоча б однієї характеристики виходить за встановлені границі, то має місце виключний варіант функціонування. Відповідне підприємство виключається із розгляду і потребує окремих рішень.

Модель траєкторії руху підприємства поліграфічної галузі - це база для аналізу стану на ринку. Дії ОПР впливатимуть не тільки на оптимізацію діяльності підприємства, а й на зміну параметрів моделей. 


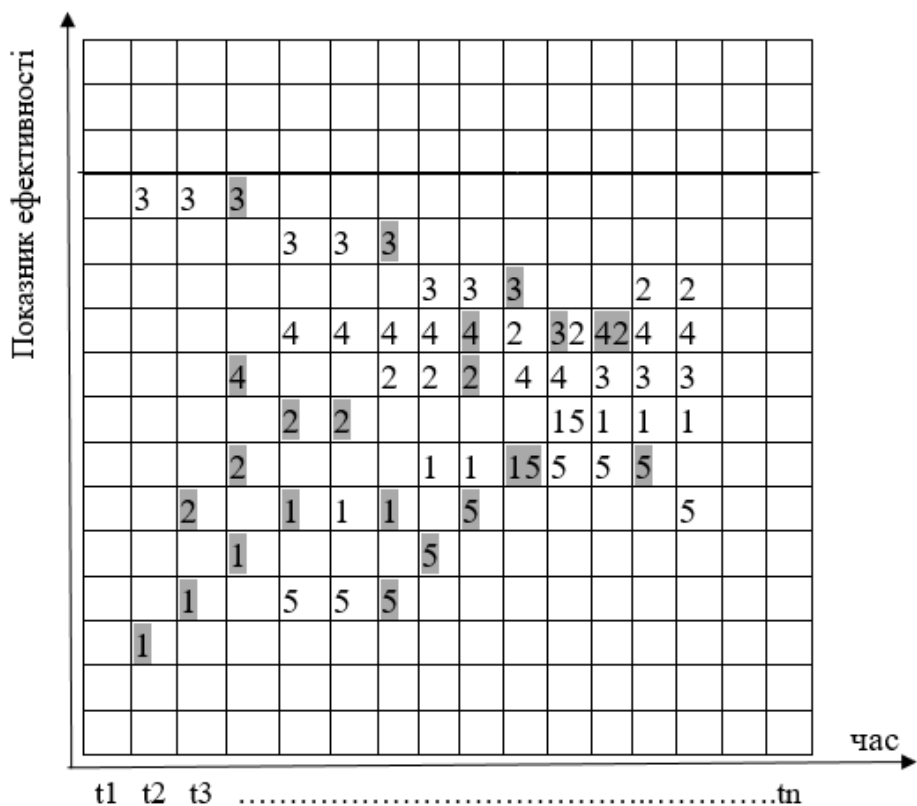

Рисунок 2 - Модель траєкторії функціонування підприємств галузі

Зокрема відомо, що життєвий цикл підприємства [15] починається 3 придбання обладнання, сировини i вирішення кадрового питання. Це потребує початкових коштів, які відносяться до основних початкових параметрів моделі.

Метод інформаційної підтримки процесів забезпечення запасними частинами виробничого обладнання промислового підприємства [16], який засновано на використанні технології інтелектуальних агентів, що дозволяе підвищити ефективність виробничих процесів, також може бути застосований для поліграфічних підприємств.

Як правило, матеріальні ресурси закуповуються для виготовлення однієї партії продукції (тиражу) за умови іiі реалізації за один період часу. Це припущення дозволяє спростити задачу моделювання.

Обладнання потрібне 3 самого початку функціонування підприємства та використовується протягом багатьох періодів виробництва, враховуючи його амортизацію.

Кількість працівників залежить від кількості придбаного обладнання та можливості роботодавця платити їм заробітну плату. Кількість вакансій залежить від об'ємів виробництва та величини заробітного фонду.

За алгоритмом роботи моделі, підприємство починає виробництво за умови наявності перелічених ресурсів і випускає продукцію в поточний період часу та одразу ж передає їі на реалізацію, результати якої відомі на початок наступного періоду часу. Обсяг наступної партії залежить від успішності реалізації поточної партії продукції, що впливає на кількість потрібної сировини та матеріалів на початку наступного періоду.

Якщо прибуток підприємства протягом декількох періодів є додатним, то, в залежності від стратегії підприємства, можна:

- розширити виробництво, збільшивши обсяги продукції, що виготовляється, - закупивши додаткові машини та обладнання, а також найнявши більше працівників;

- покращити асортимент продукції, яка випускається;

- викупити конкурентне поліграфічне підприємство, збільшивши за його рахунок основні фонди та кількість працівників.

Якщо прибуток низький або від'ємний, його можна покращити, змінюючи обсяги продукції, яка виробляється. В разі неефективності таких дій найчастіше підприємство $є$ збитковим. Коли в підприємства недостатньо коштів для закупівлі навіть мінімальної кількості сировини і виплати заробітної плати працівникам, то підприємство вважається банкрутом і перестає існувати.

Висновки. Розглянута модель процесів життєвого циклу поліграфічного підприємства 3 використанням інтелектуальних агентів, кожний $з$ яких має внутрішню структуру, програмні модулі для розв'язання окремих задач, використовує дані (як внутрішні для окремого підприємства, так і з загальної бази даних), 
робить висновки, виходячи із прагнення розвитку та максимізації прибутку.

Науковою новизною є розробка моделі підтримки прийняття рішень щодо оптимізації функціонування підприємств поліграфічної галузі на основі інтеграції елементів еволюційної та мультиагентної парадигм.

Представлена модель є поєднанням сучасних економічних математичних моделей 3 налаштуваннями для можливості застосування теорії «штучного життя».

Процес моделювання триває доти, доки необхідно зацікавленій особі. Результатом функціонування моделі $\epsilon$ набір параметрів поліграфічного підприємства, робота якого досліджувалась. Метою моделювання роботи поліграфічних підприємств в більшій мірі $є$ прогнозування, що надає можливість прослідкувати життєвий цикл потенційно створеного підприємства та спрогнозувати його перспективи в умовах конкуренції.

Виконана ініціалізація елементної бази моделювання процесів функціонування підприємств поліграфічної галузі.

Практичну цінність має розроблена методика аналізу та прогнозування діяльності поліграфічного підприємства.

Розроблена модель дозволить побачити перспективи діяльності сукупності поліграфічних підприємств, що є конкурентами, та розробити необхідну стратегію поведінки на ринку, що задовольняє ОПР.

Одержані результати спрямовані на подальший розвиток технологій підтримки прийняття рішень керівниками підприємств.

\section{Список використаних джерел}

[1] О. Ф. Волошин, та С. О. Мащенко, Теорія прийняття рішень. Київ: Київський університет, 2006.

[2] Л. Ф. Гуляницький, та Т. Г. Бондар, "Дослідження ефективності адаптивних методів прогнозування", Компьютерная математика, № 1, с. 53-60, 2018.

[3] Ю. П. Зайченко, Основи проектування інтелектуальних систем. Київ: Видавничий Дім "Слово", 2004.

[4] В. Е. Снитюк, Эволюционные технологии принятия решений в условиях неопределенности. Киев: МП Леся, 2015.

[5] Highlights on Practical Applications of Agents and Multi-Agent Systems, in
Proceedings of International Workshops of PAAMS. Salamanca, Spain, 2013.

[6] С. Бобровский, "Эволюция и искусственная жизнь", PC Week/RE, № 3, с. 26-30, 2005.

[7] M. A. Bedau, "Artificial Life: organization, adaptation and complexity from the bottom up", Trends in cognitive science, vol. 7, no. 11, pp. 505-512, 2003.

[8] H.-G. Beyer, and H.-P. Schwefel, "Evolution Strategies: A Comprehensive Introduction", Journal Natural Computing, № 1(1), pp. 3-52, 2002.

[9] G. V. Cybenko, "Approximation by Superpositions of a Sigmoidal function", In van Schuppen, Jan H. Mathematics of Control, Signals, and Systems. Springer International, pp. 303-314.

[10] N. Hansen, and S. Kern, "Evaluating the CMA Evolution Strategy on Multimodal Test Functions", in Parallel Problem Solving from Nature - PPSN VIII. Springer, 2008, pp. 282-291.

[11] L. Panait, and S. Luke, "Cooperative MultiAgent Learning: The State of the Art", Autonomous Agents and Multi-Agent Systems, no. 11(3), pp. 387-434, 2005.

[12] М. 3. Згуровский, и Н. Д. Панкратова, Системный анализ. Проблемы, методология, приложения. Киев: Наук. думка, 2005.

[13] K. Lakkaraju et al., "Research Directions for Service-Oriented Multiagent Systems", IEEE Internet Computing, vol. 9, pp. 65-70, 2005.

[14] Б. В. Мисник, "Особливості моделювання процесів функціонування виробничих підприємств на основі концепції «штучного життя»", Штучний інтелект, № 4, c. $430-437,2010$.

[15] А. А. Тимченко, и А. А. Родионов, Основы информатики системного проектирования объектов новой техники, Киев: Наук. думка, 1991.

[16] Shostak, R. Kapitan, L. Volobuyeva and M. Danova, "Ontological Approach to the Construction of Multi-Agent Systems for the Maintenance Supporting Processes of Production Equipment", in 2018 International Scientific-Practical Conference Problems of Infocommunications. Science and Technology (PIC S\&T), Kharkiv, Ukraine, 2018, pp. 209-214. URL: https://ieeexplore. ieee.org/document/8631896. 


\section{References}

[1] O. F. Voloshyn, and S. O. Mashchenko, Decision-making theory. Kiev: Kyivskyi universytet, 2006 [in Ukrainian].

[2] L. F. Hulianytskyi, and T. H. Bondar, "Investigation of the efficiency of adaptive forecasting methods", Kompiuternaia matematyka, no. 1, pp. 53-60, 2018 [in Ukrainian].

[3] Yu. P. Zaichenko, Fundamentals of Intelligent Systems Design. Kiev: Vydavnychyi Dim "Slovo", 2004 [in Ukrainian].

[4] V. E. Snytiuk, Evolutionary decision-making technologies under uncertainty. Kiev: MP Lesia, 2015 [in Russian].

[5] Highlights on Practical Applications of Agents and Multi-Agent Systems, in Proceedings of International Workshops of PAAMS. Salamanca, Spain, 2013.

[6] S. Bobrovskyi, "Evolution and artificial life", $P C$ Week/RE, no. 3, pp. 26-30, 2005 [in Russian].

[7] M. A. Bedau, "Artificial Life: organization, adaptation and complexity from the bottom up", Trends in cognitive science, vol. 7, no. 11, pp. 505-512, 2003.

[8] H.-G. Beyer, H.-P. Schwefel, "Evolution Strategies: A Comprehensive Introduction", Journal Natural Computing., no. 1(1), pp. 3522002.

[9] G. V. Cybenko, "Approximation by Superpositions of a Sigmoidal function", In van Schuppen, Jan H. Mathematics of Control, Signals, and Systems. Springer International, pp. 303-314.
[10] N. Hansen, and S. Kern, "Evaluating the CMA Evolution Strategy on Multimodal Test Functions", in Parallel Problem Solving from Nature - PPSN VIII. Springer, 2008, pp. 282-291.

[11] L. Panait, and S. Luke, "Cooperative MultiAgent Learning: The State of the Art", Autonomous Agents and Multi-Agent Systems, no. 11(3), pp. 387-434, 2005.

[12] M. Z. Zghurovskyi, and N. D. Pankratova, System analysis. Problems, methodology, applications. Kiev: Nauk. dumka, 2005 [in Russian].

[13] K. Lakkaraju et al., "Research Directions for Service-Oriented Multiagent Systems", IEEE Internet Computing, vol. 9, pp. 65-70, 2005.

[14] B. V. Mysnyk, "Features of modeling processes functioning of production enterprises on the basis of the concept «artificial life»", Shtuchnyi intelekt, no. 4, pp. 430-437, 2010 [in Ukrainian].

[15] A. A. Tymchenko, and A. A. Rodyonov, Fundamentals of computer science system design objects of new equipment. Kiev: Nauk. dumka, 1991 [in Russian].

[16] Shostak, R. Kapitan, L. Volobuyeva and M. Danova, "Ontological Approach to the Construction of Multi-Agent Systems for the Maintenance Supporting Processes of Production Equipment", in 2018 International Scientific-Practical Conference Problems of Infocommunications. Science and Technology (PIC S\&T), Kharkiv, Ukraine, 2018, pp. 209-214. URL: https://ieeexplore. ieee.org/document/8631896.

B. V. Mysnyk, Candidate of Technical Sciences,

R. B. Kapitan, Candidate of Technical Sciences, docent,

L. D. Mysnyk, Candidate of Technical Sciences, docent,

O. V. Manziura

Cherkasy State Technological University

bul. Shevchenko, 460, Cherkassy, 18006, Ukraine

e-mails: b.mysnyk@chdtu.edu.ua, 1.mysnyk@chdtu.edu.ua,kapitan_ruslan@ukr.net,

fktm-email@ukr.net

\section{PROBLEMS OF INFORMATION AND ANALYTICAL SUPPORT OF FUNCTIONING AND DEVELOPMENT OF ENTERPRISES OF PRINTING INDUSTRY IN THE CONDITIONS OF COMPETITION}

Small and medium-sized enterprises are a potential driver of Ukraine's modern economy. The large part of the market is occupied by the enterprises of printing industry. Their managers constantly come across the tasks of expanding production, re-profiling, upgrading, setting up branches or elimi- 
nating them. Given the dynamic nature of the operation of such enterprises and its duality of the process of multiagent systems functioning, it is proposed to solve such a problem on the basis of evolutionary and multiagent paradigms.

As the enterprises of the industry evolve over time, it is shown that in their modeling the ideas of the concept of "artificial life" can be used, their peculiarities, advantages and disadvantages are established. The analytical review of models, methods and software-algorithmic tools, used in the processes of support of manufacturing enterprises by stages of their life cycle, is carried out. The analysis shows the benefits of using multiagent systems in decision support systems in homogeneous environments.

Models have been built to modify multiple tasks or production structures or management strategies based on predefined rules.

The features of building an intelligent decision support system and experimental verification of results are presented. The functional structure of modular interaction in the decision support system is proposed. Features of modules functioning are defined, their input and output data flows, features of functioning and critical modes are specified.

The peculiarities of forming a knowledge base, including a database of transactions, a bank of mathematical models, a variety of mathematical methods and rules for obtaining new knowledge, are shown. The analysis of the recommendations contained in the knowledge base significantly increases the chances of the manager to make informed progressive decisions.

The above results are, in aggregate, the solution to scientific and applied research problem.

Keywords: artificial life, optimization of functioning, multiagent system, decision making, models of efficiency indicators, methods of data recovery.

Стаття надійшла 30.01.2020

Прийнято 20.02.2020 